\title{
Governing Boards and Profound Organizational Change in Hospitals
}

\author{
Mary L. Fennell and \\ Jeffrey A. Alexander
}

As popularly used, the term "governance" implies broad general responsibility for an organization, its survival, and its well-being. The process or act of governance is typically distinguished from that of management or supervision. Governance involves both the setting of organizational goals and the development of strategies for their achievement, using the traditional structure of a board of trustees, governors, or directors, to which the top administrative officer of the organization usually reports (Wisler 1986).

Virtually all hospitals (by state articles of incorporation) are expected to establish and maintain a board of trustees. Starkweather (1988) suggests that hospital trustees traditionally have had eight functions to perform: they have been charged to (1) establish institutional goals and major policies; (2) ensure that plans and programs are developed to meet corporate goals; (3) provide for the long-range financial well-being of the organization; (4) establish and maintain qualified and functioning medical staff; (5) appoint and evaluate the chief executive officer; (6) review and approve the overall organization of the hospital and the delegation of authority therein; (7) ensure that the community is well informed

Mary L. Fennell, Ph.D. is Associate Professor in the Department of Sociology at the Pennsylvania State University. Jeffrey A. Alexander, Ph.D. is Associate Professor in the Department of Health Services Management and Policy at the University of Michigan. 
concerning the organization's goals and performance; and (8) establish and maintain good procedures for conducting the affairs of the board, including the evaluation of its performance.

These functions, which derive from the "corporate" model of governance, are usually viewed as the legislated or prescribed roles, rather than the actual roles, performed by hospital boards. Indeed, Starkweather sees these functions as being carried out in a rather passive fashion by hospital boards. He notes that seven of the eight functions enumerated are usually initiated by others in the organization and are simply presented to the board for ratification. Cast in these terms, the overriding governance function in hospitals might be seen as stewardship, with trustees serving as caretakers to protect and safeguard the assets of a hospital (Shortell 1988).

Until recently, health care organizations could afford the luxury of such passive stewardship, since governance functions were carried out in the context of a positive, supportive environment. Trustees were serving in a "time of plenty," an era of cost-based reimbursement, when the willingness of society to spend money for health care and to dedicate resources to its maintenance and expansion seemed to be unlimited. Beginning in the early 1980s, however, the environment of health care organizations began to change in significant ways. These changes were characterized by increased concern about the continuing rise in the cost of medical care, substantial alteration of the financial system, shifts in the political and legal environments of health care, and important demographic trends, including the rapid aging of the population.

These and other changes have led, in less than ten years, to a far more uncertain and turbulent environment within which hospitals and their boards must function. In response to these changes, hospitals themselves have adopted new strategies and organizational structures that have placed governing boards at the vortex of change in their institutions. It falls to governance, for example, to determine ways of allocating scarce resources in the community interest, and even to define health care organizations as, in fact, community service organizations or as competitive business entities instead. According to some, trustees will be increasingly called on to provide strategic direction for the organization, to offer specific expertise, and to encourage risk taking (Barrett and Windham 1984; Shortell 1988; Starkweather 1988).

This generally turbulent environment-and changes in legal definitions of board accountability in both the care quality and financial management spheres of hospital operation, together with the general demand for lower hospital costs-has produced a flurry of recent articles in hospital journals concerning the performance of hospital boards and 
the extent to which certain board "models" can lead to better hospital performance. Underlying much of this discussion is the assumption that an optimum board structure can be defined, and that the closer a hospital is to achieving that structure, the better its overall levels of performance will be. Further, that "optimum" structure is always a departure from traditional board structure, as generally defined, and rarely is it acknowledged that boards have changed over time as hospital organization, medical technology, and hospital environments have changed.

In general, our current state of knowledge on governing board structures, processes, and influence is very incomplete. Relatively little solid evidence exists to answer the questions: do governing boards make a difference, and if so, in what way? The purpose of this article is to develop a more comprehensive, dynamic model of governing boards within hospitals and to suggest how board structures change over time. We argue that before we can determine whether, and in what ways, governing boards contribute to hospital performance, we need to know much more about variation in board structure and about the relationships of such variation to the different governance roles assumed by hospital boards. Further, we need to examine the conditions under which different board structures are likely to emerge and ways in which different board structures themselves might influence the types of profound structural changes hospitals are currently experiencing.

In our exploration of these issues we first review briefly the history of hospital governance as well as several different theoretical perspectives on hospital governance and governing boards in general, including studies in health care management, on management and economic theories of corporate boards, and on sociological theories of organizational governance. From these diverse approaches we attempt to synthesize a core set of board types and then to develop a theoretical model predicting the influence of board types on various outcomes of importance to hospitals, particularly organizational change variables.

\section{HISTORICAL OVERVIEW OF HOSPITAL GOVERNANCE}

It would be fairly easy to dismiss as ineffectual or powerless the role of governance and governing boards in hospitals if one looked at the shape and function of hospital boards only in the post-World War II era and then further assumed that no changes of consequence concerning hospital structures or their environments have occurred since then. Viewed historically, however, such a static view of hospital governance is clearly inadequate; the "ineffective" board picture has been valid only in specific 
periods of hospital and health care development. In fact, a cursory review of the historical patterns of governance in the hospital sector reveals that board roles and functions have changed as the role and function of the hospital itself has changed.

For example, in the mid- to late 1800s, hospitals were in a state of transition from almshouses to institutions designed to care for the sick and ailing. Needing capital and legitimacy, physicians were obliged to seek out sponsors for these institutions from among the merchants, bankers, lawyers, and political leaders of the local community. These sponsors could contribute money and lead subscription campaigns to support hospitals. From these needs resulted an organizational structure-in private as well as public hospitals-in which boards of "managers," trustees, governors, or commissioners, rather than physicians or professional administrators, retained final decision-making power (Barocci 1981). In exchange for sponsorship, hospitals conferred a variety of benefits and powers on trustees. These included the familiar intrinsic rewards of personal satisfaction, fulfillment of religious obligations, or need to serve the community, as well as more tangible expressions of control such as the letting of contracts, patronage, appointments, and even the admission of patients. As Starr (1982) has pointed out, in the early nineteenth century the trustees entered directly into the detailed operations of hospitals, including involvement in decisions that would now be seen as strictly medical in nature.

Changes in organization and hospital financing in the late nineteenth century, as well as rapid development in medical technology and knowledge, gradually altered the distribution of power and authority in hospitals. As the trustees' sphere of control diminished, physicians' control expanded. This devolution in lay trustee power occurred in large part as a function of shifts in control over hospital resources or income. As hospitals gradually obtained more income from patient receipts and less from donations, trustee power and centrality was replaced by physician influence. Further, expansion of the power of physician "expertise" as medical care increased in complexity made trustee involvement in operational and clinical decisions increasingly impractical (Perrow 1963). Physicians became important actors on hospital boards, as both policymakers and operational directors.

In the mid-twentieth century yet another shift occurred in the role and function of governance, as hospitals experienced increasing complexity in their internal organization as well as instability, turbulence, and complexity in their relations with outside agencies such as regulators, funders, and physician groups. Specifically, since the early 1980s, the purchasers of hospital care, predominantly federal and state governments 
and business corporations, have become concerned with rapidly escalating health care costs and have demanded that costs be controlled and unnecessary health care spending eliminated. Significantly, the nature of the cost-control measures implemented has changed radically in the last decade. Previously, cost containment had taken the form of regulatory or voluntary cooperation, or both, among health care providers. By contrast, the current environment provides a system of incentives that encourages competition among providers.

This competition has intensified since the passage in 1983 of the Medicare system of prospective payment through diagnosis-related groups (PPS/DRG), a system designed to reimburse hospitals on the basis of preset rates for specific procedures rather than on a cost-incurred basis. As third party payers continue to restrict the amount of reimbursement allowable for depreciation, return on investment, and selected medical procedures, hospitals are being pressured to identify alternative sources of funding, compete for increasingly limited resources, develop alternative lines of business, and otherwise adapt to a rapidly changing health care marketplace.

These adaptations have taken a variety of forms heretofore unknown in the hospital industry. They range from relatively peripheral structural alterations, such as joint venturing with physician groups and contracting with payers, to more radical changes such as mergers, service reorientations, acquisition by multihospital systems, corporate restructuring, consolidations, and even closures. Some have argued that these structural changes in hospitals contribute to domination by professional hospital administrators and to the relegation of governance units to external-linkage or boundary-spanning roles, with little or no internal control (Starkweather 1988). In fact, the role of governing boards in either precipitating or preventing such radical reorganizations is poorly understood. Although fundamental structural changes in organizations are influenced by environmental forces, they rarely occur without approval or at least discussion by those with decision-making powers over the entire organization, that is, by the governing board.

Critical to this discussion is the notion that the power relations, roles, and influence of hospital governance have varied as a result of the changing technology and needs of hospitals; governance has changed its function as the hospital has changed its function. This dynamic, flexible role has been abetted by the incomplete integration of physicians, management, and governance in the hospital organization. Historically, each group of actors has been only "loosely coupled" to the others, and to the daily operation of hospital care. Each group has gained or lost centrality depending on both external conditions and internal contingencies. As 
price-based competition, uncertainty, and demands for community accountability increase, it is not surprising that the role and function of boards and their relationship with management and physicians is changing again. As Starr (1982) has argued, such changes are linked to the rise of the corporate ethos in the medical care sector and by the concomitant decline of professionalism and volunteerism as dominant cultures in the hospital.

These changes are also linked to several recent legal precedents that have reinforced the need for a "new model" of hospital governance. For example, the case of Darling v. Charleston Community Memorial Hospital (1965) and its follow-ons have clearly established that the hospital and its board have direct responsibility for the quality of medical care practiced within the institution. Although physicians previously were defined as independent contractors and the hospital was not responsible for the negligent acts of its physicians, Darling changed the focus of legal responsibility, making the hospital and its board responsible for monitoring and assuring quality care. Further, other more recent cases (Schwinger v. U.S. 1987; Simpson v. U.S. 1987) have established similar fiduciary responsibilities for hospitals and trustees. These cases have established the obligation of governing boards to be diligent in performing the duties of eleemosynary corporations. Thus, as legal definitions of organizational accountability shift toward governing boards, the roles, power, and structures of boards regain center stage.

\section{REVIEW OF RESEARCH AND THEORIES ON GOVERNANCE}

\section{HOSPITAL GOVERNANCE AND PERFORMANCE}

An extensive literature exists on hospital trusteeship and governance. However, the vast majority of these writings tend to be either descriptive, focusing on general characteristics of hospital boards, or prescriptive, delineating problems with board structure, process, or roles and proposing solutions to those problems. This literature is contained, for the most part, in hospital trade and practitioner journals, and is not based on a solid foundation of theoretical and empirical research.

The American Hospital Association has grouped hospital governance literature into eight general categories, which include general trusteeship (Abbot 1981; Cunningham 1985; Mott 1984; Jellison 1983), governing board effectiveness (Bader and Associates 1983; Kovner 1985; Ewell 1987; Wilson 1984), governing board evaluation (Moses 1986a,b; Umbdenstock 1987; Huizenga and Anderson 1984), trustee-chief execu- 
tive officer relations (Ewell 1983; Doody and Fish 1980; Moses 1986a,b), trustee-physician relations (Friedman 1982; Thompson 1979; Castele 1986-1987), trustee involvement in the community (Dawson 1982; Cohen 1986), liability issues related to trusteeship (Blaes 1982; Bernstein 1983), and quality assurance (Jessee 1984; Williams and Donnelly 1982). By far, the most widely discussed topic in the governance area concerns governing board effectiveness. These writings tend to be dominated by prescriptive or normative recommendations for changes in governance process, composition, and functions based on the "hands-on experience" of either hospital managers or consultants, or both.

There is also a somewhat scant, although growing, literature on board performance and effectiveness that is more empirically based. The majority of these empirical studies have examined the relationship of board composition, structure, and process to traditional hospital performance-related outcomes such as efficiency and quality of care. Morlock and her colleagues (1987) investigated the relationship of trustee influence to quality of care. They proposed that when the chairperson of the board is active and influential in community hospitals, patients experience lower mortality rates. Although an empirical relationship was noted by the authors, they acknowledged the difficulty of establishing a causal link between governance and hospital-related outcomes.

Barrett and Windham (1984) attempted to assess the relationship between particular board types and hospital effectiveness as measured by a series of financial indicators. They found that board effectiveness depended not only on the congruency between the goals of the chief executive officer (CEO) and the board chairman, but also on the relationship between board type and the hospital's environment. Boards characterized as "analyzer" and "prospector" boards, which actively engage in environmental scanning and adjusting, were more effective in competitive environments than were "defender" and "reactor" boards, which tend to focus on internal efficiency.

Several earlier studies focused on the relationship between board composition and hospital performance outcomes. One of the first (Shortell, Becker, and Neuhauser 1976) assessed the relationship between management involvement in board activity and support department costs. In hospitals whose administrators were voting members of the board, nonmedical support departments were found to have experienced lower costs than in hospitals whose administrators were not voting members. The same study found that the percentage of reports prepared and sent to the board was more important in terms of lowering costs than was the total number of reports prepared for the board. These results suggest a potential link between board access to information and effective performance. 
The same authors focused more broadly on compositional issues and board effectiveness in a later study (Kaufman, Shortell, Becker, et al. 1979). They found that the presence of physicians on the board was related to a smaller percentage of board members from the financial and business community; however, occupational variables did not seem to be correlated with either cost or quality of care measures. Hospitals with administrative and physician representation on the board did not outperform those with more traditionally composed boards.

Finally, in a study that considered a variety of internal organizational characteristics and their relationship to hospital costs, Sloan and Vraciu (1983) found no association between characteristics of the hospital board, such as size and composition, and hospital costs. Unlike a number of previous investigations, this study employed several control variables thought to be associated with hospital costs and potentially representative of alternative explanations of the organization-cost relationship.

By and large, the hospital and health services literature on governing boards and performance does not reach any consistent conclusions regarding the relationships between board characteristics and hospital effectiveness, even though this body of research provides a variety of data about observed differences in types of boards. Indeed, in review, this literature is undecided about defining the salient characteristics of hospital boards and the relationships of these characteristics to aspects of organizational effectiveness-and even about the aspects of organizational effectiveness to consider in this context. Emphasis has primarily been on testing bivariate relationships between specific attributes of boards and operational indicators of hospital performance, without modeling any generalized function of hospital boards. These studies are further limited by very small sample sizes and inadequate methodologies to control for alternative explanations of hospital effectiveness and performance.

Perhaps most important, however, is the fact that a majority of these studies have been insufficiently grounded in theory, which has led to an unsystematic approach to governance research, particularly in the assessment of governance effect on hospital performance. More theoretically based research on hospital governance has focused on several specific topics concerning either internal power relationships, the external roles of governing boards, or change in board roles over time. We turn now to a review of the literature on each topic.

\section{HOSPITAL BOARD POWER AND AUTHORITY}

As discussed earlier, in the past, hospital governing board authority and responsibilities in internal decision making were not clearly defined. 
In some hospitals the board of trustees played an active role ir policy and program development, but in many other institutions the board performed largely ceremonial functions and either delegated or abdicated much authority for corporate decision making to the chief executive officer, the medical staff, or one or two very active board members (Morlock, Nathanson, and Alexander 1987; Prybil 1980). This state of affairs is reflected by a nearly complete omission of the topic of board power and authority in the management and research literature on health care organizations.

Economic models of hospitals, for example, typically viewed the hospital organization as essentially a physicians' cooperative (Pauly and Redisch 1973). Others employed an exchange perspective in which the only relevant actors were managers and medical staff (Jacobs 1974; Harris 1977). This perspective reflects the more general theory of managerial hegemony, which defines a board as nothing more than an extension of management's power over the organization resulting from managerial control over the selection of outside directors (Williams 1979). As described by Kosnik (1987), outside directors selected by management are "expected to rubber-stamp management's policies" (p. 167). Unfortunately, most comparative studies of hospital decision making have also failed to examine the influence of trustees in relation to other groups within the institution (Shortell 1974; Roemer and Friedman 1971; Morse, Gordon, and Moch 1974; Shortell, Becker, and Neuhauser 1976; Scott, Flood, and Ewy 1979).

Although seldom applied to studies of hospital boards, agency theory (Fama 1980) provides an alternative perspective that combines issues of board composition, effectiveness, and power/authority. Agency problems arise in corporate settings because the separation of ownership (stockholders) and professional management (agents) leads to self-interested behavior on the part of the managers. A board's internal monitoring function supposedly serves as a possible monitoring mechanism to guard against opportunistic management behavior. According to Kosnik (1987), effective board monitoring depends on the board's identification with stockholders' interests, and board members' expertise in decision making (i.e., the exercise of authority rights). In the hospital sector, the issue of ownership and control is increasingly complex, as corporate restructuring, merger, and service unbundling can lead to a blurring of the profit/notfor-profit distinction. To the extent that multiple "stakeholder" groups can be identified, agency problems presumably translate into bargaining among various interest groups vying for representation in the dominant coalition (Pfeffer and Salancik 1978).

In one of the few empirical studies related to board power and authority, Kaluzny and Veney (1972) evaluated relative perceptions of 
influence in hospital decision making among boards, medical staff, and management. Based on data collected from 49 general, acute care hospitals, they found that board members' perceptions of their own board's influence in six major decision areas was considerably lower than the perceptions of board influence held by either management or physicians. These results further confirm the incongruities regarding board power and cast doubt on the potential efficacy of board action in matters of internal policy.

Contributing to the general ambiguity regarding the board's role and function are two important paradoxes. Morlock, Nathanson, and Alexander (1987) and Provan (1988) have noted that the hospital board's decision-making authority over internal functions is continually subject to erosion by increased regulations, state budget review, health planning agencies, and the requirements of external accrediting bodies (e.g., Joint Commission on Accreditation of Healthcare Organizations). At the same time, pressures from these groups, as well as an increase in court decisions, have placed the hospital under increased public accountability and have thereby forced governing boards to become more active in many areas of decision making.

Provan (1988) points to a second paradox involving governing board authority and decision making. He notes that external pressures for cost containment under the prospective payment system together with demands for higher-quality care have tended to exaggerate differences between clinical and administrative orientations in hospitals. These differences, Provan argues, lend themselves to an active interventionist or compromising role for the board. Counterbalancing this trend, however, is the increase in complexity of hospital organization structures as well as the trend toward multicorporate systems and unbundling of hospital services. These developments have led to greater decentralization of decision making and a reduction of board influence over many internal decisions.

Several empirical studies have provided evidence regarding ambiguity and confusion over board roles and authority in practice. A study by Kovner (1974) showed that a gap existed between the areas considered of highest priority by board members and the areas they considered themselves most qualified to handle. Areas of most concern were cost control, quality of care, and relations with third party payers. The area of greatest expertise for the majority of the board was capital investment. Ritvo (1980) revealed similar findings on board process and function. His analysis of 121 Ohio hospitals indicated that boards seemed to spend their time coping with the problems at hand rather than anticipating those of the future. Ritvo found that boards relied heavily on internal data as 
opposed to external information to detect areas of concern. Not only was environmental scanning being neglected, but the result of this overreliance on internal data was an additional time delay in responding to external problems, depending on the length of time it took for external problems to be recognized or captured, or both, on internal data. Ritvo's conclusion was that this sort of information-processing structure, which focuses on internal affairs, results in a crisis-management, rather than strategic-planning, approach to governance in hospitals (Ritvo 1980).

A more recent line of inquiry in the area of hospital governance has attempted to step back from questions about the relationship of governance to hospital performance, to examine in more detail variation in board structure and composition and in board influence over specific policy-decision areas. In general, this research rests on the assumption that board structure, composition, and influence will vary systematically as a function of the characteristics of the organization itself, environmental contingencies facing the organization, and whether or not the organization is embedded in a larger corporate context.

In a recent series of empirical studies on the topic of governance authority and influence, Alexander and his colleagues examined the locus of decision-making authority (hospital versus system level), as dependent on the type of governance model used by the system (Morlock and Alexander 1986); the type of decision being made (Alexander and Schroer 1985); and various system characteristics related to complexity, age, and ownership (Alexander and Fennell 1986). These studies generally conclude that the type of system affiliation and system structure were important in understanding the nature and extent of governing board roles, influence, and autonomy.

A somewhat different line of research has focused on board relations with hospital management and medical staff under varying organizational conditions (Alexander and Morlock 1985; Morlock, Nathanson, and Alexander 1987; Provan 1988). As a whole, these studies suggest that board relations with internal and external stakeholders will vary as a function of whether or not the hospital is part of a multihospital system, by ownership or control of the hospital, and by the hospital's dependence on particular patient populations and funding sources. Findings from these studies support the general notion that hospital board structure, composition, and influence are not unidimensional. Rather, these characteristics appear to vary systematically as a function of other important hospital and environmental attributes. Hospital boards, therefore, do not play one particular role in policy-making or external relations, but appear to adapt their roles to local conditions and corporate context. Although empirical evidence is lacking, one might also assume that such board roles and 
functions change over time as the contingencies facing hospitals change and as different demands are placed on the policy-making and leadership elements of the organization, especially demands and contingencies concerning external roles of governing boards. We turn now to a consideration of both the institutional and resource-acquisition roles played by boards.

\section{THE INSTITUTIONAL ROLE OF HOSPITAL BOARDS}

The external roles and functions of hospital boards have received somewhat more attention than the internal focus in both the health services and sociological literature. Historically, the principal role of trustees was to maintain or enhance the legitimacy and prestige of the hospital and to attract resources to the institution from the surrounding environment (Kaufman, Shortell, Becker, et al. 1979; Kovner 1974; Pfeffer 1973). Theoretically, the base from which these external roles were derived can be found in Thompson's (1967) classic model of organizations as sets of nested levels. In brief, any organization can be conceptualized as a set of three nested levels: the innermost level, the core technology, consists of the production process or the core work of the organization; the second level consists of the managerial level; and the outermost level, or institutional level, consists of key boundary-spanning units such as boards and public relations units. As part of the institutional level, governing boards function to link the organization to its environment, to set overall policy and direction for the organization, and to buffer or protect more internal levels of the organization (especially the core technology) from uncertainties and disturbances posed by the environment.

More contemporary treatments of institutional-level phenomena in organizations are represented by the work of Meyer and Rowan (1977), and DiMaggio and Powell (1983); these were recently reviewed in Scott (1987). Institutional theories of organizational behavior emphasize the legitimacy-enhancing and prestige-lending functions of various organizational structures. For example, in public-sector organizations one often finds considerable dependence on certified professionals or elaborate information-processing systems, or an emphasis on cost accounting-none of which may have any demonstrated effect on productivity or performance, but all serving to signal other organizations and the public that the organization in question is rational or "modern." Organizational structures, then, can provide symbolic or ritualistic value, which enhances survival chances. 
Starkweather (1988) argues that hospital governing boards are primarily ritualistic structures used to enhance hospital legitimacy. The "myth" of board authority is "an agreeable fiction ... contrived and maintained by all three of the major hospital coalition groups": top management, physicians, and lay trustees (p. 82), which allows management to control physicians, physicians to continue to function within hospitals as autonomous entrepreneurs, and lay trustees to maintain their personal status and prestige. Further, the board structure itself allows hospital structures to correspond more closely with the rest of corporate America, thus enhancing legitimacy and forming a symbolic bridge with the larger corporate system.

\section{RESOURCE DEPENDENCE AND BOUNDARY SPANNING}

Resource-dependence theory has also been used to study the roles and structures of governing boards (Pfeffer 1973; Cook, Shortell, Conrad, et al. 1983). Borrowing Thompson's notion of boundary spanning as an organizational strategy, resource dependence assumes that organizations are not totally self-sufficient, and that all organizations need to engage in transactions (i.e., build bridges) with other actors or organizations, or both, in order to obtain resources needed for survival. Organizational performance, then, is defined in terms of survival (particularly the successful acquisition of needed resources) as well as the ability to maintain organizational autonomy vis-à-vis various transaction partners.

Pfeffer (1973) was one of the earliest researchers to study board effectiveness from a resource-dependence framework. Instead of using traditional indicators of hospital performance, such as financial ratios, mortality rates, and the like, Pfeffer viewed board effectiveness as the ability to attract resources to the institution. In a study of 57 hospitals, Pfeffer found that the size and composition of hospital governing boards was related to the hospital's environment. Moreover, the ability of a hospital to attract resources was a function of the fit between board size and composition in the environmental context of a hospital. Pfeffer's conclusions pointed to defining board effectiveness in terms of environmental linkage rather than operational measures of hospital performance.

The question of board composition has translated most recently into a subsidiary issue concerning interorganizational linkage, that is, interlocking directorates. Studies of board interlocks have also focused primarily on the corporate sector (Palmer 1983; Ornstein 1984; Mizruchi and Koenig 1986). An interlock means that the same individual is sitting on the boards of two organizations. As summarized by Mizruchi and Koenig 
(1986), an interlock can be conceptualized either as an interorganizational phenomenon used by organizations to deal with uncertain environments (as in resource dependence), or as an individual-level phenomenon, perhaps "a mechanism employed by business elites to coordinate their class interests" (Stearns and Mizruchi 1986, 522). The question of whether interlocks represent organizational or interpersonal linkages remains unanswered.

In the hospital sector it has become clear more recently that the traditional external boundary-spanning role of governing boards (i.e., to obtain needed resources) has been eroded both by the increasing complexities of hospital financing and by the rapid escalation of regulatory requirements (Maryland Hospital Education Institute 1979). Although both the management and sociological literature continues to highlight the board's so-called boundary-spanning function, emphasis is now placed on linkage to either significant interest or stakeholder groups (i.e., consumer groups and regulatory agencies such as state rate-setting or review commission) or as linkages to important elements in the institutional environment (Maryland Hospital Education Institute 1979; Umbdenstock 1979; Fennell and Alexander 1987; Morlock, Nathanson, and Alexander 1987).

Given the strategic importance of governing boards within the institutional level, both in institutional and resource-dependence theories, board influence in processes of organizational change has been surprisingly neglected in empirical research. The dual functions of boards as internal control systems and external monitoring units represents a unique focus point for both internal and external influences on organizational change. Depending on both environmental conditions and stage in the organization's development, we might expect boards to emphasize various roles differentially, as either change buffers or change catalysts. As discussed earlier, hospital adaptations to an increasingly turbulent environment have resulted in an escalation in the frequency and variety of a number of radical organizational changes. Yet our knowledge of the extent to which hospital boards influence decisions to transform hospital structure is extremely limited. The next section examines issues of organizational change, both developmental and crisis oriented, and board function.

\section{ORGANIZATIONAL DEVELOPMENT, CHANGE, AND THE ROLE OF । GOVERNING BOARDS}

The critical integration of board role and function and fundamental or profound organizational change was discussed two decades ago by 
Zald (1969) in his seminal work on the theory of boards. Zald argued that, over long periods of time, an examination of board functions would reveal an "ebb and flow of board activity, importance and power during different phases of the organization's development" (p. 109). Of particular interest are what Zald called "broad phase problems." It is during these phase problems that organizational boards are most likely to assert themselves either through board ratification and approval of managerial action, or crystallization of dissent among board members with respect to managerial policy. Similarly, Mizruchi (1983) argues that board power is most likely to be asserted during the handling of major problems or strategic decision points. In a related vein, Kosnik (1987) has argued that the effect of boards on organizational performance and change is likely to be confined to particular incidents in which the board actively intervenes in the organization's strategic decision making in order to prevent management from making decisions in conflict with stakeholders' interests. Thus, Kosnik maintains that accurate insights into the relationship of board governance and organizational change would only result from studies of situations where the board is potentially faced with "acute governance problems and choices" (p. 164). Indeed, the boardroom is the one place where different external influences of the organization meet regularly to discuss and essentially to control decisions and actions of the organization.

Of the three types of broad-phase problems Zald discusses, the most telling are life-cycle problems, particularly problems of (1) organizational genesis, (2) character formation and transformation, and (3) basic identity crisis. Organizational genesis describes the situation in which a new corporation is organized or established. In such cases, the attention is paid to formulation of policy, rules for managers and boards, and formulation of guidelines for action. To deal with decisions regarding organizational genesis, boards meet regularly and often, and board power and influence are continually used and called on (Zald 1969).

The second type of life-cycle problem concerns character crises/ transformation. This problem relates to changes in the institutional mechanisms of the organization for handling problems (recurring and basic), and conflict within the organization and with its environment. In stable environments these mechanisms provide an organization with standardized ways of coping with issues such as labor policy problems, product emphasis, market strategies, and relations with competitors. Changes in these institutionalized aspects of organizational character become board issues. Mechanisms through which boards become involved in character crises/transformation include legal requirements for boards in policy setting and conflict arbitration resulting from changing traditional or established operating patterns. 
The final category of life-cycle problems is identity crisis. These are situations in which the existence of the organization as an organization is threatened. In practice, such threats may take the form of merger, closure, or joint undertakings with other organizations that partially restrict the autonomy and independence of the organization. Under these circumstances the board will be called on to determine the type or direction, or both, of a policy that threatens to affect the identity of the organization.

More recently, theoretical development and research on organizational life cycles has moved beyond a heavy reliance on developmental notions of birth, growth, maturation, and decline, to a simpler and more comprehensive definition of stages as "clusters of subsystem problems or issues" (Whetten 1987, 338). Organizational life-cycle stages are not necessarily "progressive" and sequential; organizations can and do pass into and out of different stages and reenter earlier stages. The broad-phase problems identified by Zald can occur in various sequences and repeatedly over time. Similarly, major reorganizations are not necessarily "evolutionary" or developmental in nature. Transition paths through various changes over time may be nonrecursive, and multiple changes over time could be interdependent.

Four primary clusters of life-cycle stages can be defined from the literature: growth, decline, stability, and instability (Cameron, Kim, and Whetten 1987). Growth and decline are often conceptualized as those sets of conditions in which a substantial increase or decrease in an organization's resource base occurs over a specified period of time. Instability has been empirically defined by Cameron and coworkers as nontrivial, rapid, discontinuous, or fluctuating change in an organization's resource base; stability is defined as either the absence of change or a trivial amount of change.

In addition to these fairly lengthy stages or phases of organizational growth or decline, hospitals are currently at risk of experiencing a variety of fundamental or profound organizational changes of a more instantaneous or abrupt nature as they attempt to deal with the major environmental shifts occurring in the hospital sector. Such profound organizational change can be conceptualized in terms of Hannan and Freeman's (1984) and Pfeffer's (1982) notion of change in core attributes of the organization. Criteria for defining such changes include: (1) changes in the stated goals of the organization; (2) changes in the forms of authority within the organization; (3) changes in core technology; (4) changes in the kinds of clients or customers to which the organization orients its production, or in the ways it attracts resources from the environment; and (5) changes in the fundamental identity or autonomy of the organization as they pertain to loss of organizational culture or power to control organizational destiny, or both. 
TABLE 1 Profound Organizational Changes (POC) in Hospitals

\begin{tabular}{lc}
\hline Type of Profound Change & Effect on Autonomy of Org. A \\
\hline Corporate restructure & + \\
System affiliation: & - \\
Type I: system purchase & $?$ \\
Type II: system formation & \\
Merger: & - \\
Type I: A + B = B & + \\
Type II: A + B = A & $?$ \\
Type III: A + B = C & - \\
Service/Product change & - \\
Closure &
\end{tabular}

The hospital sector has been subject recently to at least five major types of structural change: corporate restructuring, multifirm system affiliation, merger, major service change, and closure. All of these changes have a profound effect on organizational autonomy; except for closure, however, these changes do not necessarily result in organizational failure. Further, several different types of mergers and affiliations can be defined. Mergers can take one of three different forms: in a combination of organizations $\mathrm{A}$ and $\mathrm{B}$, the remaining organization can be identified as either a third party, C, or one of the original units, A or B. Similarly, two types of system affiliation can be distinguished: situations in which an organization is purchased by a system, or in which two or more independent organizations combine to form a system.

Table 1 summarizes all eight types of profound organizational changes experienced recently by hospitals. From the point of view of Hospital A, two changes can be considered growth or diversification strategies, maintaining inherent organizational identity and autonomy and thus considered positive changes $(+)$; four changes represent a loss of autonomy $(-)$; and two changes result in the formation of a different organizational structure, either through the creation of a new firm or a multifirm system (?). In these situations the outcomes of profound organizational change with respect to autonomy are not clear; the board's decision to pursue or not to pursue these two types of changes would be fraught with considerably more informational uncertainty than in the previously described cases.

As mentioned previously, the role of governing boards in either pursuing or blocking such profound changes is poorly understood. We suggest that to answer the question "Do boards make a difference?" requires an analysis of governing board influence on these crucial decisions. 
As we have seen in our review of various literatures on board role and functions, governing boards play different roles under different sets of conditions, and board structures vary across hospitals. It is quite likely that particular board structures may be more or less likely to influence decisions to profoundly change a hospital's structure. We would also suggest, following Zald (1969), that the hospital's life-cycle stage should be included as an important contextual variable that may change the relationship between board structure and the likelihood of decisions to merge, restructure, or otherwise radically change a hospital's structure.

In the next section we present two basic models of board structure and hypothesize how these board models may influence decisions to pursue or block various profound organizational changes.

\section{A SYNTHESIS OF PREVIOUS RESEARCH AND THEORY ON BOARD STRUCTURE}

As an aid in synthesizing this lengthy review of governance and governing board structures, we turn to two conceptual models recently developed by Alexander, Morlock, and Gifford (1988) for predicting differences between governance in restructured and nonrestructured hospitals: philanthropic and corporate board models. The philanthropic model, similar to Mintzberg's "board service role" (Mintzberg 1983), is based on descriptions of boards of nonprofit organizations, while the corporate model is derived from descriptions of boards of directors in the private sector (Johnson 1986). Although the philanthropic model shares some of the symbolic functions stressed by Starkweather (1988), its role is more often to be actively engaged in traditional boundary-spanning activities. The corporate model, by contrast, is generally more strategically oriented.

Eight key characteristics of these two board types are presented in Table 2 and discussed here (based on Alexander et al. 1988). Each characteristic is assumed to vary on a continuum from the philanthropic to the corporate structure. Although these eight dimensions are important and representative characteristics of the two board models, they are not necessarily exhaustive of all factors that may distinguish between the two.

1. Board Size. Philanthropic boards are characterized by a large number of members owing to the voluntaristic nature of their activity and the broad range of interests they represent (Pfeffer 1973). Historically, the major role of hospital trustees has been to maintain or enhance the legitimacy and prestige of the insti- 
TABLE 2 Governing Board Types

\begin{tabular}{|c|c|}
\hline Plilanthropic & Corporate \\
\hline Large board size & Small board size \\
\hline $\begin{array}{l}\text { Wide range of perspectives } \\
\text { and backgrounds }\end{array}$ & $\begin{array}{l}\text { Narrow, more focused } \\
\text { perspectives/backgrounds }\end{array}$ \\
\hline Small number of inside directors & Large number of inside directors \\
\hline Little management participation & $\begin{array}{l}\text { Active management participation } \\
\text { on board }\end{array}$ \\
\hline $\begin{array}{l}\text { No formal management } \\
\text { accountability to board }\end{array}$ & $\begin{array}{l}\text { Direct management account- } \\
\text { ability to board }\end{array}$ \\
\hline $\begin{array}{l}\text { No limit to consecutive terms } \\
\text { for board members }\end{array}$ & $\begin{array}{l}\text { Limit to consecutive terms } \\
\text { for board members }\end{array}$ \\
\hline $\begin{array}{l}\text { No compensation for board } \\
\text { service }\end{array}$ & $\begin{array}{l}\text { Compensation provided for } \\
\text { board service }\end{array}$ \\
\hline Emphasis on asset preservation & Emphasis on strategic activity \\
\hline
\end{tabular}

Source: Alexander, J. A., L. Morlock, and B. D. Gifford. "The Effects of Corporate Restructuring on Hospital Policymaking." Health Services Research 23, no. 2 (1988): 311-38.

tution within the community as well as to attract resources to the hospital from the surrounding environment. Corporate boards, in contrast, tend to be smaller and more focused as a function of the narrower constituencies to which the organization is accountable (Zald 1969; Ewell 1987).

2. Heterogeneity. For similar reasons, the range of perspectives and backgrounds on philanthropic boards tends to be much broader than that of their corporate counterparts (Pfeffer 1973). This is due to the influence of a wide range of constituencies and stakeholders in philanthropic organizations in contrast to the narrower shareholder representation role assumed by most corporate boards (Johnson 1986). For these reasons, philanthropic boards are more likely than corporate boards to have members with diverse characteristics of age, gender, racial or ethnic background, area of residence, and occupation. The more "business-like" orientation of corporate boards is particularly likely to be reflected in greater occupational homogeneity.

3. Inside Directors. Inside directors are those board members who also have operational roles in the organization. Corporate boards contain a larger number of inside directors to enable outside directors to take advantage of the insiders' knowledge of the 
business, to confer prestige as a form of reward to a manager, and to achieve greater correspondence between organizational operations and policy-making (Mace 1971). Philanthropic boards, because of their emphasis on environmental linkages and community relations, typically contain fewer inside directors (Morlock and Alexander 1986).

4. CEO Participation on Board. In a corporate model board, chief executive officers in the organization play a more important role in board affairs than their counterparts on philanthropic boards. This results because the CEO of a philanthropic organization typically shares power with other professional and management groups, thus diluting his or her influence with the board (Alexander and Morlock 1985; Zuckerman, Barrett, and Shortell 1979). The corporate CEO has traditionally held more power vis-à-vis the board and the organization because of his or her ultimate authority over all aspects of the organization's operations (Mizruchi 1983). Strong executive influence on the board is viewed as improving the linkage between policy-making and operations, lessening conflict between management and board members, and facilitating selection of directors whose views are consistent with the philosophy of the organization (Johnson 1986).

5. CEO Accountability to Board. Management involvement on the board, however, is a double-edged sword. The corporate-model board, in contrast to the philanthropic board, tends to distinguish more sharply between policy-making and operations of the organization. It is more likely to see its own role as that of formulating institutional policy and strategic decision making, with delegations of responsibility and authority to the CEO for day-to-day operations. This distancing of the board from operational decisions increases the need for mechanisms that enable the board to monitor and assess CEO activities and hospital performance. Routine, formal CEO evaluations by the board are seen as an important method of monitoring and improving CEO performance, as well as a way of indirectly establishing stronger linkages between operations and policy-making (Alexander and Morlock 1985).

6. Limit to Consecutive Terms. Philanthropic boards, in contrast to corporate boards, tend to be self-perpetuating bodies wherein members of the board may either select their successors or serve on the board indefinitely (Ewell 1982). Corporate boards tend to put limitations on the number of consecutive terms board 
members may serve, to keep the board from becoming too conservative and stale (Pfeffer 1973; Kovner 1978).

7. Board Compensation. Corporate boards are also more likely than philanthropic boards to compensate their members for board service (Ewell 1982). Although corporate board members are only rarely fully compensated for the value of their time, it is felt that even a token gesture in this regard strengthens the bond between the board member and the organization. Philanthropic boards, by contrast, have traditionally avoided compensating board members because of the voluntary nature of board service (Johnson 1986).

8. Strategic Activity. In terms of board activity, philanthropic board members are likely to view themselves as trustees concerned with preserving the assets of the organization and fulfilling fiduciary responsibilities. Corporate board members are more likely to emphasize their role also in establishing overall policy direction (Prybil and Starkweather 1976; Ritvo 1980). In the current health care climate, for example, they are more likely to be concerned with the hospital's competitive position; proposals for diversification, mergers, and joint ventures; and strategic planning.

In general, these two board models hold different implications for the timing and type of profound organizational changes that are likely to occur in hospitals. Given the characteristics of corporate board structures, we would hypothesize that hospitals with a corporate-style board are more likely to pursue profound changes of an autonomy-enhancing or diversification mode (" + " changes in Table 1). Philanthropic-style boards, however, are more cumbersome, more risk averse, and more concerned with "asset preservation." Hospitals with philanthropic-style boards, then, would be more likely to experience profound changes involving autonomy loss (" -" changes in Table 1), or alternatively, to avoid all types of profound changes. However, these basic arguments linking board type and organizational change are likely to be mediated by, or conditional on whether the hospital is in a period of growth, decline, stability, or instability.

\section{PROPOSED MODEL OF GOVERNANCE IN HOSPITALS AND PROFOUND ORGANIZATIONAL CHANGE}

The model we propose of governance and profound organizational change (POC) in hospitals is summarized in Figure 1. This schematic 
FIGURE 1 Hypotheses

General: $\mathrm{H1}$ : Corporate boards $(\mathrm{CB})$ increase the likelihood of positive profound organizational changes (+POC).

H2: Philanthropic boards (PB) increase the likelihood either of no change, or of negative profound organizational changes (-POC).

Under Conditions of:

GROWTH

$\mathrm{H} 1: \mathrm{CB} \rightarrow+\mathrm{POC}$

DECLINE

$\mathrm{H} 2 \mathrm{~b}: \mathrm{PB} \rightarrow$ No POCs

STABILITY

H1a: $\mathrm{CB} \rightarrow+$ POC

H2a: $\mathrm{PB} \rightarrow-\mathrm{POC}$

$\mathrm{H} 1: \mathrm{CB} \rightarrow+\mathrm{POC}$

INSTABILITY

$\mathrm{H} 2 \mathrm{~b}: \mathrm{PB} \rightarrow$ No POCs

H1b: CB $\rightarrow$ ?POC

(uncertain POCs)

$\mathrm{H} 3$ and H4: Uncertain POCs lead to increases in board size and to a larger proportion of outside directors.

summarizes our three major sets of hypotheses: (1) the basic relationships between type of board structure and types of hospital changes expected, (2) the conditioning effects of life-cycle stage on those basic relationships, . and (3) the effects of certain types of profound changes on changes in governing board structure.

To summarize, we argue that specific structural and compositional features of hospital boards will have a significant influence on the likelihood that a hospital will engage in or resist various profound organizational changes. Further, the relationship of board structure and composition to profound organizational change will be mediated by the life-cycle stage of the hospital, that is, by whether the hospital is in a period of growth, decline, stability, or instability. These relationships are expected to hold, controlling for other structural and environmental variables (organization size, location, market structure). Finally, we argue that profound organizational change will itself result, in certain cases, in structural and compositional changes in the hospital board as the new or radically changed organization seeks-legitimacy and support in its environment.

In general, we expect corporate boards to be more effective in developing strategic policy direction for the hospital, to be more responsive and adaptive to rapid environmental change, and to be less risk averse than their philanthropic counterparts. These characteristics would result in a higher probability of corporate-model boards influencing positive 
POCs, such as growth-related mergers and corporate restructuring. Philanthropic boards, on the other hand, tend to serve a representation function, linking the hospital to the community and to critical resources in the environment. Concomitantly, philanthropic boards tend to act as an interface between the organization and its environment and, as such, to serve as a buffer for the organization against hostile environmental forces.

Because of its cumbersome size and composition, we anticipate that philanthropic boards will be less responsive to environmental stressors and less able to develop strategies that will result in positive organizational change for the hospital. In other words, philanthropic boards are more likely to be "overcome by events" and forced into accepting negative profound organizational change when environmental circumstances dictate.

Alternatively, philanthropic boards are thought to be highly effective in terms of buffering organizations from their environments. This attribute, coupled with the fact that these types of boards tend to be statusquo oriented, suggest that philanthropic boards are also more likely to be associated with the lack of profound organizational changes of any type. We hypothesize:

H1: In general, hospitals governed by corporate boards are more likely to experience positive profound organizational change than are hospitals governed by philanthropic boards.

H2: In general, hospitals governed by philanthropic boards are more likely to experience negative profound organizational change, as well as no profound change, than are hospitals governed by corporate boards.

As discussed earlier, however, we expect these relationships to differ depending on the life-cycle stage experienced by the hospital. Although $\mathrm{H} 1$ should hold under conditions of either growth or stability, experience of a stage of decline in the hospital means that the relationship between corporate-board structure and the likelihood of positive POCs will weaken (indicated by a dashed arrow in Figure 1). Even though we expect corporate-board hospitals to be less risk averse than their philanthropic counterparts, the probability of risk taking and profound change will fall off under conditions of steady decline, as the organization attempts to minimize losses and regroup. Further, if the hospital is in a stage of unstable or variable growth, we would expect hospitals with corporate boards to be more likely to attempt more uncertain strategies, such as system formation or mergers in which two organizations combine to form a third entity (Type III mergers; see Table 1). The autonomy of the 
organization may be jeopardized in these uncertain changes, but the ultimate reward could be great. Thus, the following corollaries are offered under $\mathrm{H} 1$ :

H1a: Under conditions of organizational decline, hospitals with corporate-style boards are less likely to experience a positive POC than they are under conditions of growth or stability.

H1b: Under conditions of organizational instability, hospitals with corporate-style boards are more likely to experience uncertain POCs than they are under conditions of growth, stability, or decline.

Life-cycle stage will also change the likelihood of profound organizational change within hospitals with philanthropic-style boards. However, for these types of hospitals the moderating effect of life-cycle stage functions to delineate the conditions under which either negative changes or no change is more likely to occur. As we suggested earlier, philanthropic-style boards either can function to buffer the organization from its environment, and thus preserve the status quo, or they can become cumbersome and nonadaptive in structure, thus allowing the organization to become engulfed by external forces. We hypothesize that life-cycle stage represents the key to determining the role that becomes dominant for philanthropic-style boards. When the organization is growing, or when it is relatively stable, philanthropic boards are more likely to act as effective buffers, in which case no fundamental changes are likely to occur. However, if the organization is already experiencing a downturn, the strategic incapacity of this type of board is likely to increase the probability of negative profound changes, such as purchase by a multihospital system, merger with another organization, a complete service change, or closure.

Thus, we present the following corollaries to $\mathrm{H} 2$ :

H2a: Under conditions of organizational decline, hospitals with philanthropic-style boards are more likely to experience negative profound organizational changes than they are under conditions of growth, stability, or instability.

$\mathrm{H} 2 \mathrm{~b}$ : Under conditions of organizational growth or stability, hospitals with philanthropic-style boards are more likely to experience no profound organizational change than they are under conditions of instability or decline.

In the above hypotheses we have treated board structure as the major independent variable. However, we anticipate that, under certain 
circumstances, boards will adapt and change in response to major organizational reconfiguration and environmental shifts. Specifically, we anticipate that, subsequent to profound organizational changes that result in a new organizational entity (e.g., mergers, system formation, corporate restructuring), organizations will strive to enhance external legitimacy in their environments by altering the composition or structure, or both, of their boards (Pfeffer 1973; Alexander and Fennell 1986; Fennell and Alexander 1987; Starkweather 1988). We anticipate that, for hospitals experiencing changes that result in the formation of a new organizational entity, boards will increase in size and outside representation in order to establish environmental linkages and increase organizational legitimacy in the broader environment. Conversely, in those situations where profound organizational change in hospitals does not result in a new organizational entity, less pressure will exist either to establish new linkages to environmental resources or to enhance legitimacy, or both. Based on the above, we hypothesize:

H3: Hospitals that have experienced profound organizational change resulting in the formation of a new organizational entity will increase the number of board members and representation by outside directors on the hospital governing board.

$\mathrm{H} 4$ : Hospitals that have experienced profound organizational change that does not result in the formation of a new organizational entity will experience no changes in board size or composition.

\section{SUMMARY AND CONCLUSIONS}

Over the past decade the importance of governing boards as policysetting and oversight units within organizations has increased dramatically. Although this is true for both corporate- and private-sector organizations (Bacon and Brown 1977; Gelman 1988), it is particularly relevant to the health sector. Hospital governing boards, long considered inconsequential in hospital management, have recently become subject to closer scrutiny. The role of governing boards in decisions affecting hospital strategy and hospital performance is once again a topic of some interest in boardrooms and hospital trade journals.

Impressive evidence of the renewed interest in governance is provided by the funding of an instructional consortium by the W. K. Kellogg Foundation to help strengthen trusteeship and governing board decision making, and to improve education for health services managers in the area of governance. Members of the consortium include the Hospital 
Research and Educational Trust, the American Hospital Association, the American College of Healthcare Executives, and the Association for University Programs in Health Administration. Among the activities being undertaken by this consortium is the development of a self-assessment tool/methodology for boards, a bibliography and reference guide on effective governance for practicing trustees, research workshops for faculty in health administration programs, and a teaching guide on governance and trustee leadership.

Despite this interest, the question with which we began this article persists. Do governing boards make a difference? In the course of our review of previous work on governance we found that, more often than not, that question has been transformed into: how do boards influence hospital performance? And very often that question has been further narrowed into: which board structure leads to better hospital performance?

We have argued for a respecification of the initial question. Rather than pursuing a definition of the maximally performing governing board, we should perhaps shift our focus back to a fuller understanding of board structure and function, and its influence on hospital change. The model developed here combines four essential, and very basic, questions:

1. What are the basic dimensions that underlie structural variation in different types of governing boards?

2. How do these board types influence structural change in hospitals?

3. How is the effect of board influence on change itself likely to change over time as a function of the hospital's general pattern of growth, decline, stability, or instability? And finally,

4. How does profound change in hospital structure influence, in turn, the structure of governing boards as the new or radically changed hospital seeks legitimacy and support from its environment?

Of course, this respecification of the study of hospital governing boards requires that research on boards reflect a number of methodological concerns, not the least of which is a longitudinal focus. In order to evaluate both the influence of different board models on decisions to change hospitals profoundly and the effect of hospital change on governing board size and composition, we would need comparative data on a large number of hospitals for a reasonable period of time. Both the sample size and the time frame must be large enough to allow for both a comparison of hospitals in different life-cycle stages and the modeling of the antecedents of a variety of different profound changes. 
We contend that such an approach would provide a much more dynamic picture of hospital governance than has been seen, in that the interplay of board structure, hospital structure, and larger hospital context would become much clearer than before. Hospital boards take many different roles and change structures under different sets of conditions. Given the rapidity of change in the current hospital environment, an examination of the dynamics of board structure influence on organizational change, and of ways in which the structures themselves change over time, would contribute greatly to our understanding of larger, systemwide changes in health care.

\section{REFERENCES}

Abbot, C. Governance: A Guide for Trustees and Directors. Boston: Cheswick Center, 1981.

Alexander, J. A., and K. A. Schroer. "Governance in Multihospital Systems: An Assessment of Decision Making Responsibility." Hospital and Health Services Administration 30, no. 2 (1985): 9-20.

Alexander, J. A., and L. Morlock. "Multi Institutional Arrangements: Relationships between Governing Boards and Hospital Chief Executive Officers." Health Services Research 19, no. 6, Part I (1985): 675-99.

Alexander, J. A., and M. L. Fennell. "Patterns of Decision Making in Multihospital Systems." Joumal of Health and Social Behavior 27, no. 1 (1986): 14-27.

Alexander, J. A., L. Morlock, and B. D. Gifford. "The Effects of Corporate Restructuring on Hospital Policymaking." Health Services Research 23, no. 2 (1988): 311-38.

Bader and Associates, Inc. Keys to Better Hospital Governance Through Better Information. Camp Hill, PA: Hospital Trustee Association of Pennsylvania, 1983.

Bacon, J., and J. K. Brown. The Board of Directors: Perspectives and Practises in Nine Countries. New York: The Conference Board, 1977.

Barocci, T. A. Non-Profit Hospitals: Their Structure, Human Resources, and Economic Impact. Boston: Auburn House, 1981.

Barrett, D., and S. R. Windham. "Hospital Board Adaptability to Competitive Environments." Health Care Management Review 9, no. 4 (1984): 11-20.

Bernstein, A. H. "Putting to Rest Unwarranted Fears about Trustee Liability." Trustee 38, no. 3 (March 1983): 17-18, 22-23.

Blaes, S. M. "Hospital Trusteeship: Corporate and Personal Liability." Hospital Topics 63, no. 7 (July 1982): 78-83, 86.

Cameron, K. S., M. U. Kim, and D. A. Whetten. "Organizational Effects of Decline and Turbulence." Administrative Science Quarterly 32, no. 2 (June 1987): 222-40.

Castele, T. J. "Physician-Hospital Cooperation." Health Matrix 4, no. 4 (Winter 1986-1987): 23-25.

Cohen, A. B. "Trustees' Multifaceted Job Includes Representation of Community Needs." Health Management Quarterly 3rd Quarter (1986): 7-9. 
Cook, K., S. M. Shortell, D. A. Conrad, and M. A. Morrissey. "A Theory of Organizational Response to Regulation: The Case of Hospitals." Academy of Management Review 8, no. 2 (1983): 193-205.

Cunningham, R. M. Governing Hospitals: Trustees in the Competitive Environment. Chicago: American Hospital Publishing, Inc., 1985.

Darling v. Charleston Community Memorial Hospital, 211 N.E.2D.253, 1965.

Dawson, E. E. "The Community Relations Role of the Hospital Trustee." Texas Hospitals 37, no. 9 (February 1982): 32-34.

DiMaggio, P., and W. Powell. "The Iron Cage Revisited: Institutional Isomorphism and Collective Rationality in Organizational Fields." Amcrican Sociological Review 48, no. 2 (1983): 147-60.

Doody, M. F., and L. Fish. "CEO Performance Review: A Board Responsibility." Osteopathic Hospitals 2.4 (May 1980): 8-11.

Ewell, C. M. "Talking to the Board." Hospitals 57, no. 2 (16 January 1983): 79, 81, 84.

. "The Governance Challenge: Integrating Multiple Levels." Healthcare Executive 3, no. 2 (May/June 1987): 14-17.

. "Wonderboards: How to Build Strong Governing Bodies Twelve Ways." Trustee 35, no. 10 (October 1982): 33-37.

Fama, E. F. "Agency Problems and the Theory of the Firm." Journal of Political Economy 88 (April 1980): 288-307.

Fennell, M. L., and J. A. Alexander. "Organizational Boundary Spanning in Institutionalized Environments." Academy of Managentent Journal 30, no. 3 (1987): 456-76.

Friedman, E. "Are Financial Worries Causing Boards to Turn Their Backs on Medical Staffs?" Trustee 35, no. 6 (June 1982): 15-19.

Gelman, S. R. "Roles, Responsibilities and Liabilities of Agency Boards." In Community Residences for Persons with Developmental Disabilities. Edited by J. P. Janicki, M. W. Krauss, and M. M. Seltzer. Baltimore, MD: Paul H. Brookes Publishing Co., 1988.

Hannan, M. T., and J. Freeman. "Structural Inertia and Organizational Change." American Sociological Revieze 49, no. 2 (1984): 149-64.

Harris, J. F. "The Internal Organization of Hospitals: Some Economic Implications." The Bell Journal of Economics 8, no. 2 (1977): 467-82.

Huizenga, I. C., and J. G. Anderson. "An Informal Approach to Board Evaluation." Trustee 37, no. 10 (October 1984): 38, 40.

Jacobs, P. "A Survey of Economic Models of Hospitals." Inquiry 11, no. 2 (1974): 83-97.

Jellison, M. D. "As I See It: Proper Role of the Board, the CEO, and the Medical Staff." Trustee 36, no. 8 (August 1983): 36.

Jessee, W. F. Quality of Care Issues for the Hospital Trustee. Chicago: The Hospital Research and Educational Trust, 1984.

Johnson, T. "Improving Board Effectiveness in Hospitals." Working paper, University of Pennsylvania, Philadelphia, 1986.

Kaluzny, A., and J. Veney. "Who Influences Decisions in Hospitals: Not Even the Administrator Really Knows." Modern Hospital 119 (December 1972): 52-53. 
Kaufman, K., S. Shortell, S. Becker, and D. Neuhauser. "The Effects of Board Composition and Structure on Hospital Performance." Hospital and Health Services Administration 25, no. 1 (1979): 23-37.

Kosnik, R. D. "Greenmail: A Study of Board Performance in Corporate Governance." Administrative Science Quarterly 32, no. 2 (June 1987): 163-85.

Kovner, A. R. "Hospital Board Members as Policy Makers: Role, Priorities and Qualifications." Medical Care 12, no. 12 (1974): 971-82. "Improving Community Hospital Board Performance." Medical Care 16 , no. 1 (1978): $79-89$. "Improving the Effectiveness of Hospital Governing Boards." Frontiers of Health Services Management 2, no. 1 (August 1985): 4-33.

Mace, M. Directors: Myth and Reality. Boston: Harvard University Press, 1971.

Maryland Hospital Education Institute. Hospital Boardmanship for the 80's. Lutherville, MD: Maryland Hospital Education Institute, 1979.

Meyer, J. W., and B. Rowan. "Institutionalized Organizations: Formal Structure as Myth and Ceremony." American Joumal of Sociology 83, no. 2 (1977): 340-63.

Mintzberg, H. Power In and Around Organizations. Englewood Cliffs, NJ: Prentice Hall, 1983.

Mizruchi, M. S. "Who Controls Whom? An Examination of the Relation between Management and Boards of Directors in Large American Corporations." Academy of Management Reviezo 8, no. 3 (1983): 426-35.

Mizruchi, M. S., and T. Koenig. "Economic Sources of Corporate Political Consensus." American Sociological Review 51, no. 4 (1986): 482-91.

Morlock, L. L., and J. A. Alexander. "Models of Governance in Multihospital Systems." Medical Care 24, no. 12 (1986): 1118-35.

Morlock, L. L., C. A. Nathanson, and J. A. Alexander. "Power, Influence and Authority." In Health Care Management: A Text in Organizational Theory and Behavior. Edited by S. Shortell and A. Kaluzny. New York: John Wiley \& Sons, 1987, 265-300.

Morse, E., G. Gordon, and M. Moch. "Hospital Costs and Quality of Care: An Organizational Perspective." Milbank Memorial Fund Quarterly 52, no. 3 (1974): 315-46.

Moses, R. P. Evaluation of the Hospital Board and Chief Executive Officer. Chicago: American Hospital Publishing, 1986a. "Rating Your CEO: A Guide to Effective Evaluation." Trustee 39, no. 10 (October 1986b): 11-14.

Mott, B. J. F. Trusteeship and the Future of Community Hospitals. Chicago: American Hospital Publishing, Inc., 1984.

Ornstein, M. D. "Interlocking Directorates in Canada." Administrative Science Quarterly 29, no. 2 (1984): 210-31.

Palmer, D. "Broken Ties: Interlocking Directorates and Intercorporate Coordination." Administrative Science Quarterly 28, no. 1 (1983): 40-55.

Pauly, M., and M. Redisch. "The Not-for-Profit Hospital as a Physician's Cooperative." American Economic Review 63, no. 1 (1973): 87-99.

Perrow, C. "Goals and Power Structures." In The Hospital in Modern Society. Edited by E. Freidson. London: Free Press, 1963. 
Pfeffer, J. Organizations and Organization Theory. Boston: Pitman, 1982. . "Size, Composition, and Function of Hospital Boards of Directors: A Study of Organization-Environment Linkages." Administrative Science Quarterly 18 (1973): 349-64.

Pfeffer, J., and G. Salancik. The External Control of Organizations: A Resource Dependence Perspective. New York: Harper and Row, 1978.

Provan, K. G. "Organizational and Decision Unit Characteristics and Board Influence in Independent Versus Multihospital System-Affiliated Hospitals." Journal of Health and Social Behavior 29 (September 1988): 239-52.

Prybil, L. "The Evolution of Hospital Governance." In Health Management for Tomorrow. Edited by S. Levy and T. McCarthey. Philadelphia: Lippincott, 1980.

Prybil, L., and D. Starkweather. "Current Perspectives on Hospital Governance." Hospital and Health Services Administration 21 (Fall 1976): 67-75.

Ritvo, R. A. "Adaptation to Environmental Change: The Board's Role." Hospital and Health Services Administration 25 (Winter 1980): 23-37.

Roemer, M., and J. W. Friedman. Doctors in Hospitals. Baltimore: Johns Hopkins University Press, 1971.

Schwinger v. U.S., 652 F. Supp. 464 (E.D.N.Y. 1987).

Scott, W. R. "The Adolescence of Institutional Theory." Administrative Science Quarterly 32, no. 4 (1987): 493-511.

Scott, W. R., A. B. Flood, and W. Ewy. "Organizational Determinants of Services, Quality and Cost of Care in Hospitals." Milbank Memorial Fund Quarterly 57, no. 2 (1979): 234-64.

Shortell, S. M. "Hospital Governance: An Oxymoron in Search of New Meaning." Duke National Forum on Hospital and Health Affairs, Durham, North Carolina, 1988.

."Hospital Medical Staff Organization: Structure, Process and Outcome." Hospital Administration 19, no. 2 (1974): 96-107.

Shortell, S. M., S. W. Becker, and D. Neuhauser. "The Effects of Management Practises on Hospital Efficiency and Quality of Care." In Organizational Research in Hospitals. Edited by S. Shortell and M. Brown. Chicago: Blue Cross, 1976.

Simpson v. U.S., 644 F. Supp. 43 (E.D.N.Y. 1987).

Sloan, F, and R. Vraciu. "Investor-Owned and Not-for-Profit Hospitals: Addressing Some Issues." Health Affairs 2 (Spring 1983): 25-37.

Starkweather, D. "Hospital Board Power." Health Services Management Research 1, no. 27 (1988): 74-86.

Starr, P. The Social Transformation of American Medicine. New York: Basic Books, 1982.

Stearns, L., and M. Mizruchi. "Broken Tie Reconstitution and the Functions of Interorganizational Interlocks." Administrative Science Quarterly 31, no. 4 (1986): 522-38.

Thompson, J. Organizations in Action. New York: McGraw Hill, 1967. 
Thompson, R. E. Helping Hospital Trustees Understand Physicians. Chicago: American Hospital Association, 1979.

Umbdenstock, R. J. "Governance Trustees are Closing the Gap Between Hospitals and Consumers." Hospitals 1 (April 1979): 111-15. ."Looking In/Looking Out: Board Self-Evaluation." Healthcare Executive 2, no. 3 (May/June 1987): 30-33.

Whetten, D. A. "Organizational Growth and Decline Processes." Anmual Review of Sociology 13 (1987): 335-58.

Williams, H. M. Power and Accountability: The Changing Role of the Corporate Board of Directors. The 1979 Benjamin F. Fairless Memorial Lecture. Pittsburgh: Carnegie-Mellon University Press, 1979.

Williams, K. J., and P. R. Donnelly. Medical Care Quality and the Public Trust. Chicago: Pluribus Press, 1982.

Wilson, C. "Roles for an Effective Board: A Five-Finger Exercise. Part I." Hospital Trustee (January/February 1984): 16-18. "Roles for an Effective Board: A Five-Finger Exercise. Part 2." Hospital Trustee (March/April 1984).

Wisler, T. L. "A General Model of Organizational Governance Applied to Hospital Boards." Unpublished paper, University of Chicago, 1986.

Zald, M. R. "The Power and Function of Boards of Directors: A Theoretical Synthesis." American Joumal of Sociology 75, no. 1 (1969): 97-111.

Zuckerman, H., D. Barrett, and S. Shortell. "Evaluating the Performance of Multi-Institutional Systems: The Role of Governance and Organizational Structure." In Multi-Institutional Hospital Systems. Edited by H. Zuckerman and L. Weeks. Chicago: Hospital Research and Educational Trust, 1979. 